\title{
Chemical Variation in Essential Oils of Salvia Officinalis L. Ecotypes Cultivated in Albania
}

\author{
Elvira Bazina \\ Natural Resources Sustainability and Export Markets Development Consultant, Tirana 1000, Albania.
}

Received: March 12, 2015 / Accepted: March 14, 2015 / Published: March 31, 2015.

\begin{abstract}
Salvia officinalis L. was cultivated in different geographic locations of Albania. Sage plants originated from imported seeds and wild Albanian plants. Around 30 chemical compounds were identified in the essential oils of all cultivated sage plants; the latter were found to be very rich in camphen, $\beta$-thujone, $\alpha$-pinene, eucaliptol, rich to moderate in $\beta$-pinene and camphor, and less rich in $\alpha$-thujone and limonene. Sharp differences in chemical composition patterns and content of individual chemical compounds were noticed between and within cultivation sites. Cultivated sage was poorer in $\alpha$-thujone versus wild plants. Cultivated sage, of Albanian wild plants origin, was the richest in $\alpha$-thujone (18.45\%) versus imported seeds sage. $\beta$-thujone over-dominated $\alpha$-thujone in all cultivated sage plants. Volatile characters of cultivated sage were indicative of the species but not of the geographic origin of plant material. Variation in essential oils composition and chemical compounds' content (biosynthetic pathways) in cultivated sage is related more to the genetic background than the environmental factors. If cultivating sage in Albania, then wild local ecotypes would be best to use as $\alpha$-thujone is maintained at satisfactory levels, local natural base is preserved, unnecessary hybridization with imported seeds sage is prevented, and are more resistant and cost effective.
\end{abstract}

Key words: Sage, Headspace-GC/MC, chemical composition, variation, cultivation.

\section{Introduction}

Albania, a lush Mediterranean country with cool, cloudy, wet winters and hot, clear, dry summers and terrain mostly mountainous and hilly with small plains along the Adriatic and Ionian coast, has been endowed by nature with a vast and unique diversity of MAPs (Medicinal and Aromatic Plants). The latter represent nearly $10 \%$ of Albania's flora [1]. Around $30 \%$ of all known European species of plants are found in Albania [2,3]. Over $90 \%$ of MAPs are grown and collected from the wild. They are processed in the country and exported as dried, essential oils and fresh aromatic sachets [2, 3]. MAPs collection is an important source of income for thousands of rural families living in remote areas of the country [2,3].

Albania's MAP exports, during 2013, reached 11,221 ton experiencing an increase of $15 \%$ against

Corresponding author: Elvira Bazina, M.Sc., research field: biotechnology.E-mail:elbazina@gmail.com. previous year [4].

Sage continues to be Albania's major MAPs export item [2-4] positioning Albania for years as leader in sage supply to the US market. Albanian sage accounted for $84 \%$ (Fig. 1) of total sage imports, in tones to the US market during 2014 [5].

There has been a significant increase in direct sage exports from Albania to the US market [5] over the years (Graph. 1). The increase is also attributed to the in country value adding of sage prior to export including organic certification, "ground" and "whole leaf" quality, up to-date processing equipment and facilities, etc. And that, in turn, has commended higher export prices providing more income to the Albanian supply value chain.

The growing market demand for Albanian wild sage (dried/essential oils) and inappropriate harvesting practices make imperative the identification and implementation of sustainable and commercially competitive supply options for instance "in situ" 


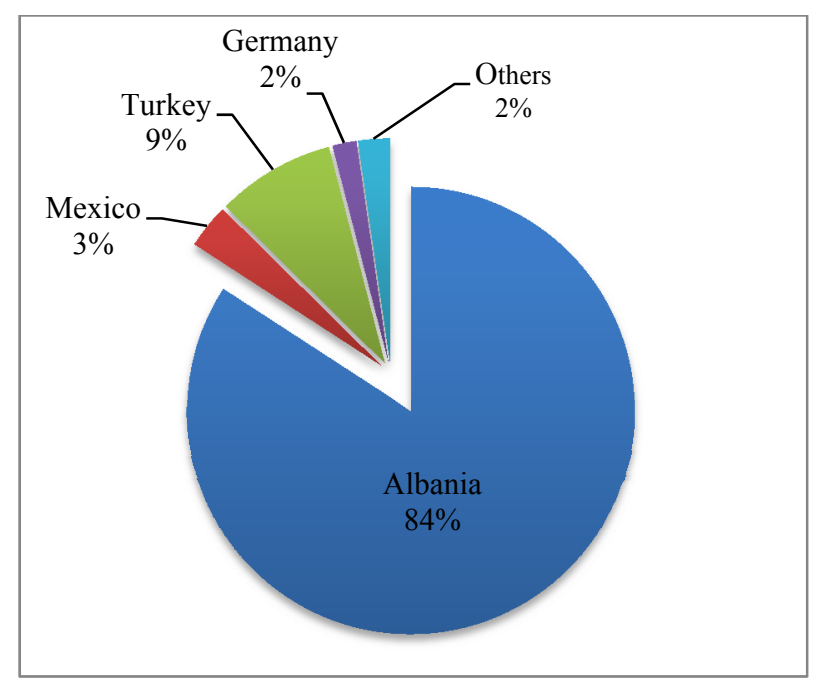

Fig. 1 Albania's market share in Sage imports to USA.

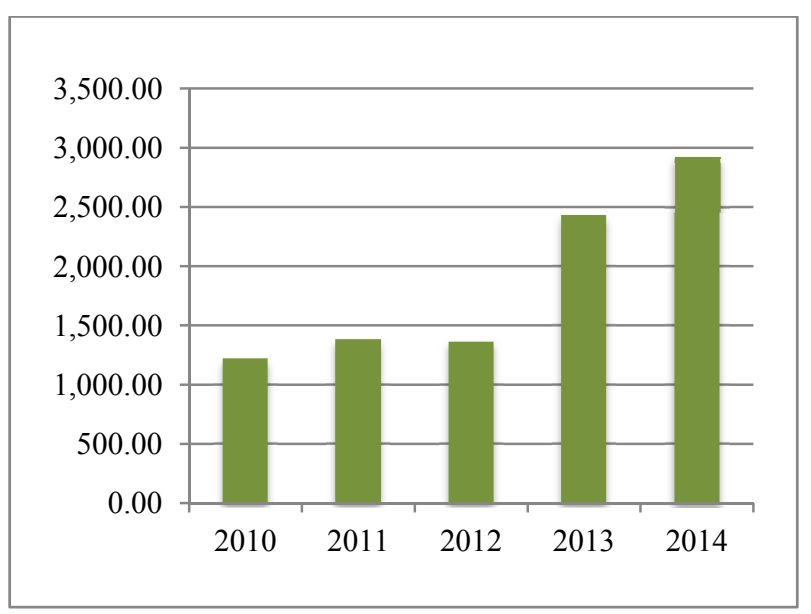

Graph 1 Trend of Albania's sage exports to USA.

cultivation if feasible economically, qualitatively and eco-friendly.

Cultivated sage plants were examined in the studyinorder to (1) identify the chemical composition profiles ofeach cultivated sage ecotype, (2) examine the chemical variation among sage ecotypes cultivated in different geographic regions of Albania, and (3) contribute to the research work on Salvia officinalis L. in Albania.

\section{Materials and Methods}

Salvia officinalis L. was cultivated in seven different geographic locations of Albania being North (Lezhë/LE; Koplik/KO), Northeast (Dibër/DI), Center (Lushnjë/LU), South (Libohovë/LB) and Southeast
(Skrapar-Strënec/ST; Skrapar-Jaupas/JP). Sage plants were obtained from imported seeds, from Holland and Germany, except for one location (Dibër) where vegetative cuttings from wild local populations were used. Five samples per location were randomly picked prior to flowering stage (early June), and then fully dried at room temperature to avoid any potential contamination that would affect samples' quality.

Samples were analyzed at the LGC Health Sciences Fordham, Cambridgeshire/UK (www.lgcgroup.com) using Headspace-Gas Chromatography/Mass Spectrometry method. Analysis of the headspace fraction of the sage plant material was carried out with an Agilent GC 7890 (HP7890/MSD) with a mass spectrometer detector 5973 (Instrument reference/SS-GCMS-4) coupled to a Gerstel MPS Headspace Injection.

Approximately $140-150 \mathrm{mg}$ of sample (dry sage leaves) was accurately weighed into a $10 \mathrm{~mL}$ headspace vial and heated for $10 \mathrm{~min}$ at $90{ }^{\circ} \mathrm{C}$. Then $1000 \mu \mathrm{L}$ of the headspace fraction was injected to the GC. The GC analysis was carried out with aRxi 624Sil MS column of $30 \mathrm{~m}$ long, $0.25 \mathrm{~mm}$ i.d. and 1.4 $\mu \mathrm{m}$ film thickness. The injector temperature was $200{ }^{\circ} \mathrm{C}$ and the oven temperature was programmed at an initial temperature of $40{ }^{\circ} \mathrm{C}$ for $10 \mathrm{~min}$. The temperature was then increased at a rate of $12{ }^{\circ} \mathrm{C} / \mathrm{min}$ up to $190^{\circ} \mathrm{C}$ and retained at this temperature for $5 \mathrm{~min}$. An additional programme was needed to elute the less volatile compounds at a rate of $6{ }^{\circ} \mathrm{C} / \mathrm{min}$ up to $225^{\circ} \mathrm{C}$ and retained at this temperature for $5 \mathrm{~min}$. The carrier gas was helium with $1 \mathrm{~mL} / \mathrm{min}$ flow rate, constant; the split ratio was 1:5. The make-up gas was nitrogen. The liner was a $4 \mathrm{~mm}$ split liner containing glass wool; spectrum purge was $3 \mathrm{~mL}$ per minute. Detector type was MSD, SCAN mode, $50-1000 \mathrm{~m} / \mathrm{z}$ and the mass spectra were taken at $70 \mathrm{eV}$ from 35 to $650 \mathrm{~m} / \mathrm{z}$. The source and quadrupole temperatures were $230{ }^{\circ} \mathrm{C}$ and $150{ }^{\circ} \mathrm{C}$ respectively. Components were identified comparing the retention times and spectral data from 
the NIST standard reference database. Due to the quantity of peaks generated during the analysis, peaks with areas $>0.1 \%$ have been considered.

\section{Results}

Upon examination of thirty-five cultivated sage samples, around 30 compounds were identified including monoterpenes (comprising about 70\%), sesquiterpenes, alcohols, acids, sulphides, etc. A snapshot of major chemical compounds identified in the sage plants according to cultivation site is presented below (Table 1):
Essential oils of cultivated sage in the present study showed to be highly rich in camphene, a-pinene, eucalyptol, $\beta$-thujone, rich to moderatein $\beta$-pinene and camphor, and less rich in $\alpha$-thujone and limonene. Other compounds such as $\beta$-caryophyllen, $\alpha$-phellandrene, borneol, bornyl acetate, carene, cymene, $\beta$-ocymene, sterene were found in small to trace amounts. Sporadically other compounds were identified such as azulene, naphthalene, panasinsene, terpinolene, isoamilene, methylthyometan, trans- $\beta$-amylene, cyclene, 1,5-hexadiene, dimethyl sulphide, 1.5.5trimethyl, ethanethiol, etc.

Table 1 Qualitative and Quantitative variation of major chemical compounds amongst cultivated Sageplants.

\begin{tabular}{|c|c|c|c|c|c|c|c|c|c|c|c|c|c|c|}
\hline \multicolumn{2}{|c|}{ Samples } & \multirow{2}{*}{$\begin{array}{c}\text { a - } \\
\text { thujone }\end{array}$} & \multirow{2}{*}{$\begin{array}{c}\text { B- } \\
\text { thujone } \\
17.4\end{array}$} & \multirow{2}{*}{$\begin{array}{c}\begin{array}{c}\text { Camph } \\
\text { ene }\end{array} \\
17.9\end{array}$} & \multirow{2}{*}{$\begin{array}{c}\text { Camph } \\
\text { or }\end{array}$} & \multirow{2}{*}{$\begin{array}{c}\begin{array}{c}\text { Euca } \\
\text { lyptol }\end{array} \\
8.5 \\
\end{array}$} & \multirow{2}{*}{$\begin{array}{c}\begin{array}{c}\text { a - } \\
\text { pinene }\end{array} \\
10.9 \\
\end{array}$} & \multirow{2}{*}{$\begin{array}{c}\begin{array}{c}\text { B - } \\
\text { pinene }\end{array} \\
8.9 \\
\end{array}$} & \multirow{2}{*}{$\begin{array}{c}\text { Limo } \\
\text { nene } \\
2.3\end{array}$} & \multirow{2}{*}{$\begin{array}{c}\begin{array}{c}\text { a - phellan } \\
\text { drene }\end{array} \\
2.1 \\
\end{array}$} & \multirow{2}{*}{$\begin{array}{c}\begin{array}{c}\text { Cyclopropane,1.1- } \\
\text { dimethyl-2-(2- } \\
\text { metthyl-2-propenyl)- }\end{array} \\
2.5 \\
\end{array}$} & \multirow{2}{*}{$\begin{array}{c}\begin{array}{c}\text { Born } \\
\text { eol }\end{array} \\
0.7 \\
\end{array}$} & \multirow{2}{*}{$\begin{array}{c}\begin{array}{c}(+)-4- \\
\text { Carene }\end{array} \\
-\end{array}$} & \multirow{2}{*}{$\begin{array}{c}\text { 1,5,5-trimethyl- } \\
\text { 6-methylene- } \\
\text { cyclohexene }\end{array}$} \\
\hline & 1 & & & & & & & & & & & & & \\
\hline \multirow{4}{*}{$\frac{\underline{x}}{\frac{0}{a}}$} & 2 & 18.5 & 2.4 & 18 & 9 & 18.6 & 13.3 & 8.1 & 3.5 & 1.5 & 0.2 & 0.6 & - & - \\
\hline & 3 & 5.1 & 15 & 14.5 & 5.4 & 19 & 15.2 & 9.3 & 3 & 1.4 & 3 & 0.5 & - & - \\
\hline & 4 & 9 & 15.1 & 13.4 & 5.6 & 23 & 9.9 & 9.6 & 2.8 & 1.5 & 0.3 & 1.6 & - & - \\
\hline & 5 & 4.6 & 18.4 & 14.6 & 4.2 & 8.7 & 26 & 6.1 & 3.3 & 1.4 & 2.5 & 0.5 & - & - \\
\hline \multirow{5}{*}{ 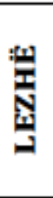 } & 1 & 6.2 & 24.2 & 14.9 & 11 & 4.6 & 6.9 & 6.7 & 4.3 & 1.5 & 10.6 & 0.2 & 0.4 & - \\
\hline & 2 & 5.6 & 24.5 & 15.2 & 11 & 3.6 & 7 & 7.2 & 4.4 & 1 & 10.2 & 0.2 & - & - \\
\hline & 3 & 3.1 & 11.5 & 22.2 & - & 4.9 & 20.8 & 9.9 & 5.7 & 0.3 & 1.6 & 0.2 & - & - \\
\hline & 4 & 9.7 & 18 & 15.8 & 11.6 & 11.3 & 9.4 & 6.4 & 5 & 1.2 & 5 & 0.2 & - & - \\
\hline & 5 & 2.9 & 17.7 & 20.5 & 14.9 & 7.6 & 10.7 & 6.1 & 6.1 & - & 5.8 & 0.5 & - & - \\
\hline \multirow{5}{*}{$\begin{array}{l}\underline{y} \\
\underline{a} \\
\underline{a}\end{array}$} & 1 & 4.8 & 22.5 & 7.07 & 5.1 & 910 & 28.5 & 5.9 & 3.4 & 0.3 & 4.3 & - & - & - \\
\hline & 2 & 4.6 & 20.8 & 7.5 & 5.2 & 9.6 & 29.4 & 5.9 & 3.5 & 0.8 & 4.2 & - & - & - \\
\hline & 3 & 0.6 & 6.2 & 21.4 & - & 17.5 & 0 & 7.2 & 6.7 & 0.3 & 2.8 & 0.6 & 0.2 & - \\
\hline & 4 & 5.5 & 18.8 & 14.7 & 9.3 & 16.3 & 11.2 & 6.9 & 4.4 & 1.4 & 4.2 & 0.2 & 0 & - \\
\hline & 5 & 4.5 & 14.6 & 19.4 & 10 & 13.8 & 14 & 4.8 & 4.9 & 0.3 & 5.9 & 0.4 & 0 & - \\
\hline \multirow{5}{*}{$\underset{n}{\underline{z}}$} & 1 & 7 & 20.2 & 10.4 & 6.2 & 11.1 & - & 6.6 & 3.3 & 1.4 & 3.4 & 0.3 & 23.4 & - \\
\hline & 2 & 12.4 & 13.7 & 16 & 8.4 & 14.7 & 11.6 & 10 & 2.6 & 2.3 & 2.8 & 0.2 & 0.2 & - \\
\hline & 3 & 2 & 13.2 & 23.4 & 13.2 & 6.2 & 16.4 & - & 4.7 & 0.2 & 2.7 & 0.7 & 0.2 & - \\
\hline & 4 & 3 & 18.2 & 17.2 & 9 & 17.3 & 10.6 & 9 & 5.7 & 1.7 & 2.6 & 0.2 & 0.1 & - \\
\hline & 5 & 6.1 & 19.7 & 16.2 & 9.3 & 12.8 & 10.5 & - & 3.7 & 0.2 & 5 & 0.3 & 0 & - \\
\hline \multirow{5}{*}{ 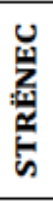 } & 1 & 3.3 & 12.6 & 17.8 & - & 14.7 & 13.6 & 9.5 & 3.6 & 0.2 & 4.3 & 0.6 & 0.3 & - \\
\hline & 2 & 3.4 & 19.7 & 15.9 & 10.1 & 14.8 & 10.2 & 7.2 & 4 & 0.3 & 7.6 & 0.2 & 0.6 & - \\
\hline & 3 & 2.2 & 11.7 & 21.2 & 11.8 & 13.2 & 15 & 9.9 & 4.7 & 0.2 & 2.1 & 0.8 & 0.2 & - \\
\hline & 4 & 4 & 21.2 & 9.85 & 5.4 & 12.3 & 19.8 & 7.6 & 2.3 & 0.23 & 8.5 & 0.3 & - & - \\
\hline & 5 & 2.8 & 15 & 18.7 & 10.8 & 17.3 & 13.2 & 7.4 & 5 & 0.3 & 3 & 0.2 & - & - \\
\hline \multirow{5}{*}{\begin{tabular}{l}
$n$ \\
$\vdots$ \\
$\vdots$ \\
\hdashline
\end{tabular}} & 1 & 4.7 & 14.7 & 21.9 & 12.9 & 7.5 & 13.8 & 7.8 & 4.6 & 2.2 & 4.4 & 0.3 & - & - \\
\hline & 2 & 2.5 & 7.7 & 22 & 10.9 & 7.9 & 20 & 5.3 & 5.8 & 0.4 & 1.8 & 0.9 & - & - \\
\hline & 3 & 2.5 & 8.9 & - & - & 7.7 & 15.6 & 5.1 & 6.1 & 0.3 & 1.8 & 0.6 & - & 26.6 \\
\hline & 4 & 9.7 & 20.2 & 13.9 & 6.5 & 7.3 & 11.3 & 4.5 & 10.9 & 1.7 & 1.7 & 0.5 & 0.3 & - \\
\hline & 5 & 1.8 & 8.4 & 28 & - & 5 & 18 & 4.6 & 7 & 0.3 & 2.41 & 0.5 & - & - \\
\hline \multirow{5}{*}{ 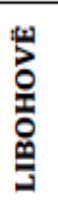 } & 1 & 6.3 & 17.9 & 10.86 & 5.3 & 15.4 & 19.7 & - & 3.4 & 1.5 & 4.3 & 0.2 & - & - \\
\hline & 2 & 11.3 & 13.4 & 16.2 & 6.6 & 11.6 & 14.7 & 11.9 & 2.8 & 2 & 4 & 0.3 & 0.2 & - \\
\hline & 3 & 4 & 10.3 & 15.66 & 9.3 & 19.3 & 13.9 & - & 4.7 & 1.5 & 3.8 & 0.5 & - & - \\
\hline & 4 & 5.7 & 10.1 & 12.1 & 6.5 & 16.3 & 25 & 12.3 & 4 & 1.2 & 1.6 & 0.2 & - & - \\
\hline & 5 & 12.3 & 23 & 13 & 5.5 & 11.5 & 15.5 & 9 & 1.9 & 1.8 & 1.5 & 0.2 & - & - \\
\hline
\end{tabular}




\section{Discussion}

Bellomaria [6], following previous work made by Garcia et al. (1975) and Cabo et al. (1987) [cit.7,8] described four groups of Salvia species based on the main components of their essential oils; species rich incineole and thujone (S. officinalis L.), species rich in camphor and cineole (S. lavandula Vahl.), species rich in linalool and linalyl acetate (S. sclarea L.) and species containing terpenoids of different types. Results of the present study indicate that sage plants, even though cultivated, were quite rich in cineole and thujone; this is related to the species type, which in this case is $S$. officinalis L. Therefore, essential oils are important informative characters of a given species. The "cultivated" status may explain the high contents of particularly camphene, $\alpha$-and $\beta$-pinene, which in wild sage populations are at much lower levels [9-11].

Franz [12] indicates that variation in the composition of essential oils within a given species appears to be a rule rather than exception; and is influenced by three major factors: (a) individual genetic variability, (b) plant parts and developmental stage, and (c) environment. All these factors influence plants' biosynthetic pathways, and subsequently the relative proportions of their compounds.

In the present study (Table 1), variation in the essential oils profiles of cultivated sage between locations was quite distinct, which one would think tobe related to the environmental differences. However, significant differences were noticed even within the same cultivation site where content of a given chemical compound varied from zero to maximum levels; for instance $\alpha$-pinene/Koplik (0-29.34\%), camphene/Jaupas (0-28\%), camphor/Lezhë $\quad(0-14.9 \%), \quad \beta$-pinene/Libohovë $(0-12.22 \%)$. This variation may be explained with the origin of the plant material, which were imported seeds (breeding/selection). But, most importantly chemical differences were noticed even amongst sage plants, originating from and cultivated within the same eco-zone of the wild ecotypes (Dibër case). These differences may be attributed to the age and developmental stage of the mother plants (ontogenesis), time of obtaining the cuttings, variability within the same plant populationdue to potential hybridization over the years (genetic background), etc.

It is worth mentioning extreme occurrence of a given compound, despite the geographic location of the cultivation site or origin of the mother plant. For example, 1,5,5-Trimethyl-6-methylene-cyclohexene was absent in all sage plants under investigation except for Jaupas/JP2 where it reached a maximum of $26.62 \%$, or(+)-4-carene, which was almost lacking in all cultivated sage plants but one, Lushnjë/LU1, where it reached a maximum level of $23.42 \%$ (Table 1). This is related to the genetic make up of each individual sage plant.

Sage plants cultivated in Dibër, originating from wild Albanian ecotypes, were the richest in thujone (total of $\alpha$-and $\beta$-) of all locations reaching 20-31.08\%. Whereas, Koplik and Lezhë in particular, which were the closest to Dibër geographically but imported seeds were used, generated much lower levels of it varying $6.8-27.27 \%$ in Koplik and $14.61-30.34 \%$ in Lezhë. Furthermore, sage plants of the Dibër location (local ecotypesused for cultivation) were the richest in $\alpha$-thujone (single compound) of all sage plants of all sites under study (Table 1). There were differences in $\alpha$-thujone content even between sage plants of this location, varying from $4.6-18.45 \%$ (up to 4 times), yet the Albanian ecotypes, even though brought to cultivation in lower altitudes and with less sun exposure, still generated much higher $\alpha$-thujone amounts of all cultivated sage plants of all locations. This may be explained with the origin of the mother plants (Albanian ecotypes versus imported seeds) rather than the environmental factors.

Wild sage of Northern Albania (Lezhë, Koplik, Shkodër) is characterized by high amounts of $\alpha$-thujone [9-11]. In the present study, cultivated sage 
of imported seeds, generated much lower contents of $\alpha$-thujone reaching 0.607-5.5\% (Koplik) and 2.86-9.7\% (Lezhë). Thus, the same environmental factors (same soil texture/structure and climate) generated essential oils profiles quite different from those of the wild populations. This once again emphasizes that genetic background dominates significantlythe environmental factors.

Variation in $\alpha$-thujone content between cultivated sage (present study) and wild sage [9, 10], for the same geographical locations, is presented graphically (Graph 2). It is quite noticeable the sharp difference in $\alpha$-thujone content; this may be explained with the "status" of the sage plants (spontaneous or cultivated), which leads to plants genetic background of the plant material.

There has been long debate over the years on the side effects of thujone. Scientific Committee on Food of the European Council [13] indicates that $\alpha$-thujone acts as a GABA blocker and is 3 times more potent than $\beta$-thujone, and that thujone causes epileptiform convulsions and seizures in humans. However, it is agreed that the database regarding thujone exposure via medicines should be expanded; yet current limits (up to nearly $7 \mathrm{mg} /$ day) are sufficiently protective for consumers [13-17]. Consumers and businesses' education is vital; on the other hand meeting markets' demand is important, too. Thus, if $\alpha$-thujone content will be the commercial indicator of the sage batches for export from Albania, then wild sage, especially Dalmatian ecotypes of the north of Albania that are proved [9-11] to be rich in $\alpha$-thujone, would be best to be used sustainably as source of supply (carry on the consolidated tradition of Albania in wild sage exporting). If cultivating sage, then northern $\alpha$-thujone rich local ecotypes (versus imported seeds) would be an attractive/efficient option as $\alpha$-thujone content is maintained at satisfactory levels, the wild local recourse base is preserved, unnecessary hybridization of Albanian sage population with imported seeds produced sage is avoided, and most importantly are cost effective.

$\beta$-thujone over-dominated $\alpha$-thujoneinall cultivated sage plants under study, despite the geographic location and origin of plant material. Averaging the content of $\alpha$-thujone of sage samples per each location, separately from $\beta$-thujone, the variation in $\alpha$ - and $\beta$-thujone content (in \%) between locations is quite sharp (Graph 3). Therefore, if thujone low ecotypes (rich in $\beta$-thujone) are preferred, then cultivated sage can be considered as an option for supplying "thujone safe" sage products. However, one must make sure that there is a sound demand for Albanian cultivated sage products in order to best orient investments in time and capital.

Asllani [9, 10] and Schmiderer [11] provide sound evidence on the geographic origin of the Albanian sagebased on the essential oils profiles. Wild Albanian

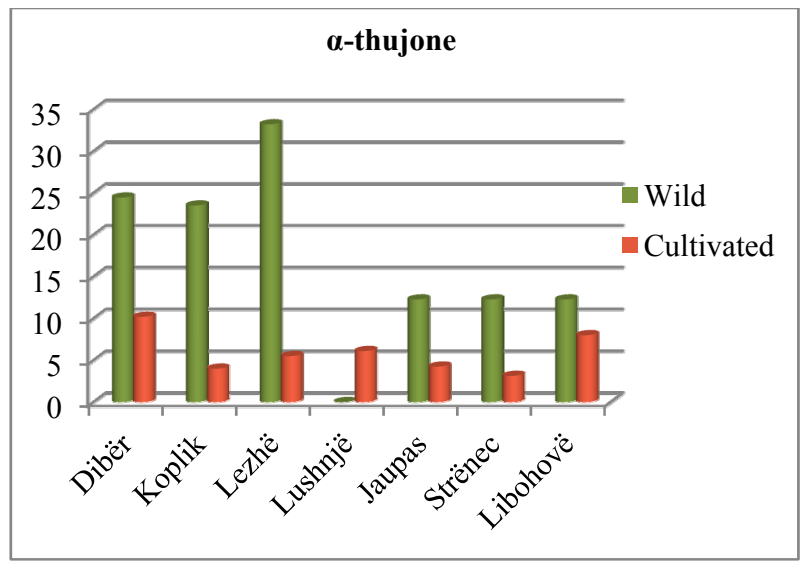

Graph 2 a-thujone content, wildvscultivated sage.

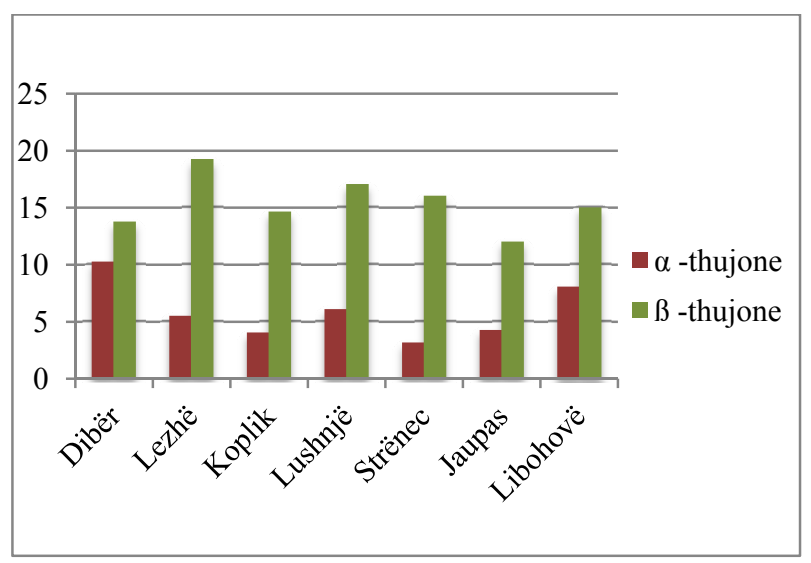

Graph 3 Differences in $\alpha$ - and $\beta$-thujone in cultivated sage. 
sage, North chemotypes, are quite rich in thujone ( $\alpha$ thujoneover dominating $\beta$-thujone), poor in camphor, poor in 1,8 cineole, and very poor in $\alpha$ - and $\beta$-pineneand camphene. South chemotypes are rich in camphor, rich in 1,8 cineole, poor in thujone (in both $\alpha$ - and $\beta$-thujone), and very poor in $\alpha$ - and $\beta$-pinene and camphene.

The present study reveals that cultivated sage plants, despite the geographic location of the cultivation site (North, Northeast, Centre, South, Southeast) all followed the same pattern-considerably poor in $\alpha$-thujone, very rich in $\beta$-thujone, relatively poor in camphor, rich in 1,8 cineole, and very rich in $\alpha$ - and $\beta$-pineneand camphene (Table 1).

This pattern is quite different from what has been previously reported [9-11] on wild Albanian sage. Therefore, unlike wild sage, essential oils of cultivated sage do not allow for accurate characterization of plants' geographic origin. However, essential oils profiles may be informative characters in terms of the origin of the plant material (wild versus cultivated).

It was quite obvious that each sage plant had a unique chemical composition pattern of essential oils; thus each cultivated sage plant represented an individual sage chemo-type. This significant variation might be influenced somehowby various factors such as ontogenesis (in agreement with [18]), cultivation schemes such as harvesting time, sun exposure, altitude, irrigation, drainage, use or fertilizers, etc. (in agreement with [19]), and environmental factors (in agreement with [20]). But above all, it is related mainly to the quality of the plant material (genetic make-up). This finding is in agreement with [7, 21-24] which concluded that variation in the volatile oils pattern is more related to the genetic background of each individual (intrinsic factors) rather than to environment (extrinsic factors).

There is a need in Albania for a closer collaboration between the herb and spice industry, academic and research institutions and relevant stakeholders to fully explore and inform on the current state of the herb and spice ecotypes and their respective profiles. Furthermore, training and education on the preservation of Albanian natural resources as well as the international markets' demand, requirements and trends is crucial for sustainable and competitive development of the Albanian herb and spice industry in the long run-"sustainable business is good business". There is an immediate need for the identification and monitoring the "commercially competitive initiatives" i.e. cultivation. Recent chaotic developments in the country have led to sage cultivation with no prior accurate technology and market knowledge. Even though sage cultivation might be an attractive option yet Albanian farmers/collectors and entrepreneurs would be best to consider the economics and ecological aspects of it.

\section{Conclusions}

Headpace GC/MS was very efficient in the chemical profiles' characterization of cultivated sage plants.

Cultivated sage plants were found very rich in camphen, $\beta$-thujone, $\alpha$-pinene, eucaliptol, rich to moderate in $\beta$-pinene andcamphor, and less rich in $\alpha$-thujone and limonene.

Significant chemical variation existed between and within cultivation sites; the basis for this variation is related to the genetic background rather than environmental factors.

Chemical differences even amongst cultivated plants, originating from the wild Albanian ecotypes, are also explained with the genetic make-up of each individual plant rather than the environmental factors.

Hence, biosynthetic pathways (chemical composition profiles, relative proportions of each chemical compound) are mainly determined by the intrinsic factors (genetic background of each individual plant) rather than extrinsic factors.

Albanian sage ecotypes would be best to consider if/when cultivation activities undertaken due to similarity of their chemical composition profiles to the 
wild sage and plants morphology, resistance to pest/diseases and harsh weather conditions.

Research work is needed to identify the current wild plant ecotypes/genotypes and their chemical profiling as well as appropriate genotypes, eco-zones and techniques for cultivation. This will greatly impact the preservation of Albanian authentic resource plants base and the competitiveness of the Albanian herb and spice export products.

It may be prudent that Albanian MAP exporters always declare status ("wild"; "cultivated") of their sage export products especially as Albania wishes to join the European Union and that the international buyers have developed innovative traceability techniques (even at the DNA level).

Essential oils patterns of cultivated sage are not indicative of the geographic origin of the plant material; yet these secondary metabolites provide significant informative evidence to the academic and, in particular, the business community. Hence

- If $\alpha$-thujone rich sage is preferred, then wild Albanian sage, especially from the North, would be best to (sustainably) collect/supply;

- If $\alpha$-thujone rich sage is preferred, alternatively cultivated sage originating from local Albanian ecotypes would be best to work with;

- If $\alpha$-thujone low sage is preferred, then cultivated sage can be an attractive option.

\section{Acknowledgement}

Many thanks to the staff of the LGC Health Sciences Fordham, Cambridgeshire/UK, especially Giovanna Meija, for their guidance and extensive technical support while carrying out the analysis. Appreciation for Prof. Dr. L. Dinga for her continuous support.Deep gratitude to Mr. Kenn Underwood for the financial support to this research work.

\section{References}

[1] Rakaj, M., Pifko, D., Shuka 1., and Barina, Z. 2013. "Catalogue of Newly Reported and Confirmed Vascular Plant Taxa from Albania (1990-2012).” Wulfenia 20:
$17-42$.

[2] FAO/TRAFFIC. 2010. Expert Consultation on Institutional Needs for Sustainable Non-Wood Forest Product Sector in Southeast Europe; Country Presentation, Albania; Bazina E. http://www.fao.org/regional/SEUR/ events/sarajevo/sarajevo_en.htm.

[3] Bazina, E. 2012. "Enabling Sustainable Management of Non-Wood Forest Products in SoutheastEuropeAlbania's Experience." Journal of life Sciences 6 (12): 1391-5.

[4] Ministry of Agriculture, Food and Consumers Protection of Albania, Directorate General ofAgricultural Policies. Export of agricultural and livestock products for 2013.www.bujqesia.gov.al/files/pages_files/Eksport-imp ort_viti_2013.pdf.

[5] United States Department of Agriculture, Foreign Agricultural Services. www.usda.fsa.gov.

[6] Bellomaria, B., Arnold, N., and Valentini, G. 1992. "Contribution to the Study of the Essential Oils from Three Species of Salvia Growing Wild in Eastern Mediterranean Region.” J. Esent. Oil Res. 4: 607-14.

[7] Bazina, E. 2000. "Evaluation of the Genetic Relatedness of Selected Clones of Salvia Officinalis Using RAPD Markers and Comparison with Volatile Oil Profiles." M.Sc. Thesis. Mediterranean Agronomic Institute of Chania, Crete, Greece.

[8] Then, M., Lemberkovics, E., and Marczal, G. 2003. "Study of Plant Anatomical Characteristics and Essential oil Composition of Hungarian Salvia Species". Proc. Int. Conf. on MAP. Eds. Bernath, J. et al., Acta Hort. 597, ISHS 2003. pp.143-8.

[9] Asllani, U. 2004."Esencat e BimëveAromatike e Mjekësore të Trevave Shqiptare.” Fq. 217-43.

[10] Asllani, U. 2000. "Chemical Composition of Albanian Sage Oil (Salvia Officinalis L.)”. J. Essent. Oil Res. 12: 79-84.

[11] Schmiderer, C., Torres-Londono, P., and Novak, J. 2013. "Proof of Geographical Origin ofAlbanian Sage by Essential Oil Analysis.” Biochem. Syst. Ecol. 51: 70-7.

[12] Franz, C. 1993. Genetics. On: Hay RKM \& Waterman PG (eds.), Volatile Oil Crops: Their Biology, Biochemistry and Production, pp. 63-96, Longman: Harlow, UK.

[13] European Commission, Health \& Consumer Protection Directorate General, ScientificCommittee on Food. 2002. Opinion of the Scientific Committee on Food on Thujone.SCF/CS/FLAV/FLAVOUR/23 ADD2 Final 6 February 2003.

[14] European Medicines Agency (EMA). 2011a. Community Herbal Monograph on Salvia Officinalis L., Folium (London, UK).

[15] European Medicines Agency (EMA). 2011b. Public 
Statement on the Use of HerbalMedicinal Products Containing Thujone. EMAHMCP/732886/2010 (London, UK).

[16] Lachenmeier, D. W., and Uebelacker, M. 2010. "Risk Assessment of Thujonein Foods andMedicines Containing Sage and Wormwood-Evidence for a Need of Regulatory Changes." Regulatory Toxicology and Pharmacology 58: 437-43.

[17] Pelkonen, O., Abass, K., and Wiesner, J. 2013. "Thujone and Thujone-Containing Herbal Medicinal and Botanical Products: Toxicological Assessment." Regulatory Toxicology and Pharmacology 65 (1): 100-7.

[18] Lakusic, B. S., Ristic, M. S., Slavkovska, V. N., Stojanovic, D. Lj., and Lakusic, D. V. 2013. "Variation in Essential Oil Yields and Compositions of Salvia Officinalis (Lamiaceae) at Different Developmental Stages.” Botanic Serbica 37 (2): 127-39.

[19] Piccaglia, R., and Marotti, M. 1989. "Effect of Mineral Fertilizers on the Composition of Salvia Officinalis oil." J. Essent. Oil Res. 2: 73-83.

[20] Li, Y., Craker, L.E., Potter, T. 1996. "Effect of Light Level on Essential Oil Production of Sage (Salvia
Officinalis) and Thyme (Thymus vulgaris)." Acta Hort., 426: 419-26.

[21] Skoula, M., El-Hilali, I., and Makris, A. 1999. "Evaluation of the Genetic Diversity of Salviafruticosa Mill. Clones Using RAPD Markers and Comparison with the Essential Oil Profiles." Biochem. Syst. Ecol. 27: 559-68.

[22] Bazina, E., Makris, A., Vender, C., and Skoula, M. 2002. "Genetic and Chemical Relations among Selected Clones of Salvia Officinalis L.." In: Breeding Research on Aromatic and Medicinal Plants, edited by Johnson, C., and Franz, C. Florida: CRC Press.

[23] Bazina, E., Makris, A., Vender, C., and Skoula, M. 2002. "Genetic and Chemical Relations among Selected Clones of Salvia Officinalis L."Journal of Herbs, Spices and Medicinal Plants 9 (4): 269-73.

[24] Jug-Dujakovic, M., Ristic, M., Pljevljakustic, D., Dajic-Stevanovic, Z., Liber, Z., Hancevic, H., Radic, T., and Savotic, S. 2012. "High Diversity of Indigenous Populations of DalmatianSage (Salvia Officinalis L.) in Essential Oil Composition." Chem. Biodivers. 9: 2309-23. 